\title{
Wages, Pensions, and Public-Private Sector Compensation Differentials for Older Workers
}

\author{
Philipp Bewerunge ${ }^{1} \&$ Harvey S. Rosen ${ }^{2}$ \\ ${ }^{1}$ Neuss Associates, New York, USA \\ ${ }^{2}$ Department of Economics, Princeton University, Princeton, New Jersey, USA \\ Correspondence: Harvey S. Rosen, Department of Economics, Princeton University, Princeton, NJ 08544, USA. \\ Tel: 609-258-4000.E-mail: hsr@princeton.edu
}

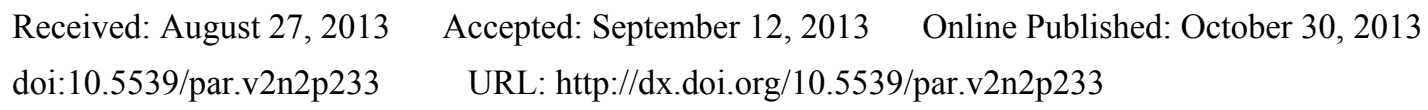

\begin{abstract}
We use a sample of full-time workers over 50 years of age from the 2004 and 2006 waves of the Health and Retirement Study (HRS) to investigate whether workers in federal, state, and local government receive more generous wage and pension compensation than private sector workers, ceteris paribus. With respect to hourly remuneration (wages plus employer contributions to defined contribution plans), federal workers earn a premium of about $28 \log$ points, taking differences in employee characteristics into account. However, there are no statistically discernible differences between state and local workers and their private sector counterparts, ceteris paribus. These findings are about the same whether or not indicators of occupation are included in the model. On the other hand, pension wealth accumulation is greater for employees in all three government sectors than for private sector workers, even after taking worker characteristics into account. As a proportion of the hourly private-sector wage, the hourly equivalent public-private differentials are about 17.2 percent, 13.4 percent, and 12.6 percent for federal, state, and local workers, respectively. We find no evidence that highly-educated individuals are penalized by taking jobs in the public sector, either with respect to wages or pension wealth.
\end{abstract}

Keywords: public-sector compensation, wages, pensions

\section{Introduction}

For many years, both academics and public policy makers have debated whether public sector workers are overor under-paid relative to their private sector counterparts. This issue has recently received particular attention because of the severe budgetary constraints facing governments at all levels. For example, former Governor Mitch Daniels of Indiana argued, "We have a new privileged class in America... We used to think of government workers as underpaid public servants. Now they are better paid than the people who pay their salaries... Who serves whom here? Is the public sector - as some of us have always thought - there to serve the rest of society? Or is it the other way around?" (Garofalo, 2010). At the same time, some public employees maintain that they are underpaid. A seventh-grade English teacher demonstrating against Wisconsin Governor Scott Walker's plan to reduce public sector benefits told the Huffington Post, "I can't get a home loan. I set my thermostat at 62 . No cable at my house, no internet...I'm also \$36,000 in debt from becoming a teacher" (Delaney, 2011).

New Jersey Governor Chris Christie (2010) captured the essence of the issue nicely when he said, "at some point, there has to be parity between what is happening in the real world and what is happening in the public-sector world." But determining what "parity" means in this context is challenging for two reasons. First, the human capital of public and private sector workers may differ. If, for example, public sector workers have more education than private sector workers, then it is neither surprising nor objectionable that they earn higher wages. This is precisely the argument made by former White House budget director Peter Orszag regarding federal government compensation: "Basically the entire delta between private sector and public sector federal government average pay can be explained by education and experience... while there may be some remaining disparities, I think some of the more dramatic newspaper stories I've seen about that disparity are somewhat misleading" (Tuutti, 2010). The second reason why public-private sector comparisons are problematic is that compensation consists of more than just wages and salaries. Pension benefits comprise an important part of compensation, so that comparisons of just wages and salaries may be misleading. Indeed, sectoral differences in pension benefits have recently drawn considerable attention. According to Cook (2011), "union chiefs can 
downplay their pension benefits all they want. The fact is, most of their members have been guaranteed a millionaire's retirement." Public-sector unions argue that such criticism is hyperbolic and unjustified. In the words of Hetty Rosenstein, New Jersey Director of the Communications Workers of America, "there's pension envy because people who are working in the private sector, they're being denied pensions" (Mulvihill, 2011).

In any case, it is clear that a sensible approach to measuring an overall compensation differential requires considering both wages and pension benefits. Further, the analysis of pension differentials needs to take into account that, because pensions are a form of compensation, their magnitude is determined in part by employee characteristics, just as is the case for wages and salaries. Simply examining average pension benefits across sectors is not an appropriate way to estimate sectoral differentials.

A great deal of research on public-private sector wage differentials has been done, including careful analysis of micro-level data on individual employees that takes into account differences in workers' characteristics. In contrast, there has been little work using micro-level data on differences in pension wealth across sectors. Furthermore, the few attempts to integrate wages and pension benefits into more comprehensive measures of sectoral compensation differentials use different data sets from different time periods to estimate the wage and pension components of the differential. In this paper, we use a single data set and a unified econometric approach to estimate wage and pension wealth differentials between public and private sector workers. Compensation packages, of course, have other components, including employment security, paid vacation, health insurance benefits, and so on. (Note 1) Our analysis focuses on wages and pension benefits because they are of major importance and micro data are relatively accessible.

Section 2 surveys the existing research on public-private sector compensation differentials. Section 3 discusses our dataset, the Health and Retirement Study, and presents summary statistics for the key variables. Section 4 presents the econometric setup and basic results. We find that the hourly wages of federal government workers are about $28 \log$ points more than private sector workers with similar characteristics, ceteris paribus. However, there are generally no statistically discernible differences between state and local workers and their private sector counterparts with similar characteristics. On the other hand, pension wealth accumulation is generally greater for employees in all three government sectors than for private sector workers, even after taking worker characteristics into account. As a proportion of the hourly private-sector wage, the hourly equivalent public-private differentials are 17.2 percent, 13.4 percent, and 12.6 percent for federal, state, and local workers, respectively.

Section 5 presents several alternative econometric specifications to assess the robustness of the results. We find that controlling for occupation leaves our substantive conclusions unaffected. Further, there is no evidence that highly educated workers are disadvantaged by working in the public sector. Section 6 concludes with a summary and some suggestions for future research.

\section{Previous Literature}

The relevant literature can be classified into three broad categories: public-private sector wage differentials, pension benefit differentials, and total compensation differentials, which include both wages and pension benefits. We now discuss each of these topics in turn.

\subsection{Wage Differentials}

The literature on wage differentials between public and private sector employees spans roughly four decades, originating with Smith's (1976a, 1976b, 1977) seminal papers. The core of her analysis is the estimation of conventional human capital earnings functions. For example, in Smith (1976b) she uses 1973 CPS data to estimate for each gender a regression of the logarithm of the wage on various worker characteristics such as years of schooling and race, including a series of dichotomous variables indicating whether each individual worked in the federal, state, or local government sectors (the private sector is the omitted category). For males, she finds wage differentials relative to the private sector of 19 percent in federal government and -4.9 percent in local government. The coefficient on the state government variable is statistically insignificant. The differentials for female workers are 31 percent in federal government, 12 percent in state government, and 3.6 percent in local government.

Papers subsequent to Smith's have modified her approach by trying to correct for self-selection of workers into various sectors, (Note 2) by using panel data to estimate fixed effects models, (Note 3) and by estimating models on a state-by-state basis. (Note 4) A fair way to summarize the findings in this literature is as follows: a robust result, found in almost all the research from Smith's early papers on, is that there is a substantial positive wage differential for federal employees, even after controlling for worker characteristics in the standard way. (Note 5) 
However, there is less agreement about state and local government workers. Positive, negative, and zero differentials have all been estimated, sometimes within the same paper.

\subsection{Pension Differentials}

Data are available on average pension characteristics by sector, including the proportion of plans that are defined benefit (DB), that is, plans in which future benefits are based on a formula involving years of service, age, and so on, and defined contribution (DC), that is, plans in which future benefits are based on a cash balance in a pension account. (See, for example, Clark, Craig, \& Ahmed, 2009) However, sophisticated econometric analyses using micro data like those for sectoral wage differences are rare. A notable exception is Quinn's (1982) important study of a sample of older workers from the 1969 Retirement History Study. Quinn estimates a regression of his pension wealth measure on dichotomous variables designating federal, state, local, and postal workers, and includes the number of years of job tenure and the final wage rate as control variables. He estimates pension wealth differentials of 72 percent for federal workers, 80 percent for state workers, and 30 percent for local workers.

Quinn does not control for differences in worker characteristics such as schooling, gender, and race. In addition, his computation of pension wealth excludes DC plans. While such a decision was sensible at the time Quinn was writing, this is no longer the case, as DC plans have become an important component of pension wealth, particularly in the private sector. According to Munnell and Perun (2006), the share of private DC plan assets out of all private pension plan assets increased from 22 percent in 1980 to 50 percent in 2004, and the corresponding share of active participants increased from 35 percent to 70 percent over the same period. Our analysis takes advantage of a more suitable estimate of pension wealth that encompasses both DB and DC plans.

\subsection{Aggregating Wage and Pension Differentials}

Some recent research has sought to integrate wages with fringe benefits in order to obtain a broad measure of sectoral compensation differentials. Using data from the Health and Retirement Study for 1992-2000, Ramoni-Perazzi and Bellante (2007) combine federal, state, and local employees to form a single "public" category, and use the standard approach to estimate a public-private sector wage differential that ranges from 3.5 to 11 percent. They next compute the difference in the average sectoral fringe benefit share of total compensation from Bureau of Labor Statistics data (which are not corrected for differences in the demographic composition of workers across sectors). Adding this figure to their estimated wage differential, they find a total public-private sector compensation difference that ranges from 6 to 14 percent. (Note 6) Other studies following the same general approach are Keefe (2010), Allegretto and Keefe (2010), Bender and Heywood (2010), Thompson and Schmitt (2010), Cannon (2011) and Gittleman and Pierce (2012), all of whom study sub-federal levels of government, and the Congressional Budget Office (2012), which examines federal government compensation. To our knowledge, no analysis of public versus private sector compensation patterns has estimated both wage and pension wealth differentials using a unified multivariate econometric framework based on micro-level data. Our data allow us to do so.

\section{Data}

Our analysis sample comes from the 2006 wave of the Health and Retirement Study, a longitudinal study of Americans aged 50 and over, who are interviewed every two years by the Institute for Social Research at the University of Michigan. (Note 7) Because the HRS is primarily based on older workers, our results might not apply to employees throughout the age distribution. (Note 8) However, in addition to standard demographic data, the HRS has information on sector of employment (Note 9) as well as a rich set of variables on pension benefits, which makes it invaluable for making compensation comparisons that go beyond wage and salaries.

All variables relating to worker characteristics, hourly pay, pension plan types, and employer pension contributions are either included or directly calculated from the original 2006 Core dataset and tracker file. Data on pension wealth are obtained from a supplement constructed by Gustman, Steinmeier, and Tabatabai (2010). They note that there is some evidence of errors in reports of pension values, and the accuracy of the reports does not improve over time (p. 213). However, they argue that the estimates do not appear to be systematically biased. If the reporting errors differed systematically by sector of employment then this would bias our estimates of pension differentials. There is no evidence with respect to whether pension wealth estimates for public sector employees are more or less accurate than their private sector counterparts.

A total of 4,759 respondents provide salary and wage information. Respondents are also asked about the number of hours worked in a typical week and the number of weeks worked per year, allowing us to calculate total hours worked per year and hourly pay. This information is available for 4,344 respondents. We drop from the sample 
the self-employed as well as part-time workers, defined as individuals who worked fewer than 1,500 hours per year. (Note 10) This leaves us with 3,199 observations. Furthermore, we exclude respondents who, while earning a positive hourly wage, earned less than the minimum wage or characterized themselves as retired (Note 11). Finally, we drop workers for whom information is missing for any of our right hand side variables, leaving us with 2,496 observations, which comprise our basic analysis sample. There are 1,907 respondents in the private sector, 115 in federal government, 225 in state government, and 249 in local government. Compared to the entire sample of 4,759 individuals who reported wage and salary information, this sample is slightly younger (mean age of 58.2 years versus 59.5 ) and has fewer black workers (9.0 percent versus 9.7 percent) and female workers (47.8 percent versus 51.4 percent).

Table 1. Dependent variable definitions and summary statistics*

\begin{tabular}{|c|c|c|c|c|c|}
\hline Variable & Description & $\begin{array}{l}\text { Private } \\
\text { Sector }\end{array}$ & $\begin{array}{c}\text { Federal } \\
\text { Government }\end{array}$ & $\begin{array}{c}\text { State } \\
\text { Government }\end{array}$ & $\begin{array}{c}\text { Local } \\
\text { Government }\end{array}$ \\
\hline$W A G E$ & $\begin{array}{l}\text { Hourly pay in } 2006 \\
\text { Dollars }\end{array}$ & $\begin{array}{c}23.22 \\
(31.40)\end{array}$ & $\begin{array}{c}31.56 \\
(34.54)\end{array}$ & $\begin{array}{c}44.09 \\
(218.49)\end{array}$ & $\begin{array}{c}22.70 \\
(10.56)\end{array}$ \\
\hline DBPlan & $\begin{array}{l}1 \text { if respondent has primary defined } \\
\text { benefit pension plan }\end{array}$ & $\begin{array}{c}0.206 \\
(0.405)\end{array}$ & $\begin{array}{c}0.556 \\
(0.499)\end{array}$ & $\begin{array}{c}0.668 \\
(0.472)\end{array}$ & $\begin{array}{c}0.744 \\
(0.437)\end{array}$ \\
\hline DCPlan & $\begin{array}{l}1 \text { if respondent has primary defined } \\
\text { contribution pension plan }\end{array}$ & $\begin{array}{c}0.420 \\
(0.494)\end{array}$ & $\begin{array}{c}0.300 \\
(0.460)\end{array}$ & $\begin{array}{c}0.241 \\
(0.429)\end{array}$ & $\begin{array}{c}0.154 \\
(0.361)\end{array}$ \\
\hline HPlan & $\begin{array}{l}1 \text { if respondent has primary hybrid } \\
\text { pension plan }\end{array}$ & $\begin{array}{c}0.041 \\
(0.197)\end{array}$ & $\begin{array}{c}0.086 \\
(0.281)\end{array}$ & $\begin{array}{c}0.045 \\
(0.208)\end{array}$ & $\begin{array}{c}0.039 \\
(0.194)\end{array}$ \\
\hline $\operatorname{Emp} C^{* *}$ & $\begin{array}{l}\text { Hourly employer contribution to } \\
\text { respondent's DC plans in } 2006\end{array}$ & $\begin{array}{c}2.22 \\
(5.12)\end{array}$ & $\begin{array}{c}2.11 \\
(4.44)\end{array}$ & $\begin{array}{c}2.29 \\
(2.66)\end{array}$ & $\begin{array}{c}0.78 \\
(0.45)\end{array}$ \\
\hline$W A G E+D C$ & Sum of Wage and EmpC & $\begin{array}{l}23.95 \\
(32.2)\end{array}$ & $\begin{array}{c}32.33 \\
(34.67)\end{array}$ & $\begin{array}{c}44.48 \\
(218.5)\end{array}$ & $\begin{array}{c}22.78 \\
(10.36)\end{array}$ \\
\hline Pension $W^{* *}$ & $\begin{array}{l}\text { Sum of pro-rated present value of } \\
\text { future benefits from most important } \\
\text { DB plan and cash balances in all DC } \\
\text { plans in } 2004\end{array}$ & $\begin{array}{c}113,515 \\
(179,497)\end{array}$ & $\begin{array}{c}205,682 \\
(218,432)\end{array}$ & $\begin{array}{c}196,930 \\
(264,745)\end{array}$ & $\begin{array}{c}190,786 \\
(260,060)\end{array}$ \\
\hline PositivePW & 1 if pension wealth $>0$ & $\begin{array}{c}0.416 \\
(0.423)\end{array}$ & $\begin{array}{c}0.946 \\
(0.226)\end{array}$ & $\begin{array}{c}0.884 \\
(0.321)\end{array}$ & $\begin{array}{c}0.867 \\
(0.341)\end{array}$ \\
\hline $\begin{array}{c}\text { Number of } \\
\text { Observations*** }\end{array}$ & & 1,907 & 115 & 225 & 249 \\
\hline
\end{tabular}

* This table shows means and standard deviations for dependent variables by employment sector, weighted by 2006 respondent weights. WAGE, EmpC, WAGE+DC, and Pension $W$ are measured in 2006 dollars.

** Means and standard deviations for Pension $W$ and EmpC are computed over positive observations.

*** These are the maximal number of respondents with non-zero sample weights in each sector. However, not every question is answered by all respondents; therefore, the number of observations varies slightly across variables.

Table 1 presents definitions and summary statistics for our dependent variables. WAGE is hourly pay in 2006 dollars. Federal and state government employees earn substantially more than either private sector employees or employees in local government. Three dichotomous variables indicate whether a given respondent has a primary (most important) pension plan of a specific type. DBPlan indicates a primary defined benefit plan, DCPlan indicates a primary defined contribution plan, and HPlan indicates a hybrid plan, which has attributes of both 
DB and DC plans. Respondents who either refused to or did not know how to answer the question about their primary pension plan were excluded from the part of our analysis that involves these variables (37 respondents did not know their primary plan type or refused to identify it).

$E m p C$ is the amount contributed by the employer to all of the worker's DC plans per hour (in 2006 dollars), conditional on it being positive. It includes both the basic contribution and any matching amounts. Respondents can provide information on employer pension contributions for up to four DC plans as either a percentage of pay (in which case $E m p C$ is calculated as the reported fraction multiplied by $W A G E$ ) or as an amount per some unit of time (in which case the conversion to an hourly basis proceeds along the same lines as for WAGE). Several respondents either did not know their employer's contribution or refused to answer the question. In total, we were able to calculate positive hourly employer contributions for 806 workers out of the 1,262 workers who reported having at least one $\mathrm{DC}$ plan.

$W A G E+D C$ is defined as the sum of $W A G E$ and $E m p C$, that is, wages and salaries plus employers' contributions to DC plans. There is not much difference between the average values of $W A G E+D C$ and the figures for $W A G E$ in the first row. Differences in DC coverage are not large enough to exert substantial effects on wage and salary differences.

PensionW is pension wealth as calculated by Gustman, Steinmeier, and Tabatabai (GST) (2010). It is defined as the sum of the present value of future pension benefits based on work to date from a respondent's most important DB plan (Note 12) and the cash balances in all DC plans on the current job in 2004 (in 2006 dollars). More precisely, GST take a worker's expected annual DB payments while in retirement and discount them back to the expected time of retirement. (Note 13) They then further discount these figures back to 2004. The specific discount rate, of course, plays a central role in these calculations. GST (2010) use a discount rate of 5.8 percent, consistent with the figure used by the Social Security Administration in its long-term projections (p. 338). (Note 14)

Since the value of a DC plan in 2004 is a cash balance that has been accumulated based on work to date, the value of a DB plan in 2004 also needs to reflect the fraction of its total value that has accrued to it based on work to date. In order to make this adjustment, GST (2010) assume that a given worker will continue to work for his employer up to retirement and multiply the total present value of the DB plan by the number of years of service for the current employer in 2004, divided by the total (anticipated) number of years of service at the time of retirement. Adding the DC cash balances to this adjusted DB present value yields a measure of total pension wealth.

We use the 2004 value because 2004 is the most recent year that GST calculate it for all workers. (Note 15) Pension $W$ is available for respondents in our analysis sample who were interviewed in both 2004 and 2006, and worked for the same employer in both years-2,100 of the 2,496 respondents in our analysis sample.

The variable PositivePW is one if the individual has positive pension wealth and zero otherwise. According to the figures in Table 1, employees in all levels of government are more likely to have positive pension wealth than private sector workers, and conditional on having pension wealth, their average values are also higher. Both the probability of having positive pension wealth and the conditional mean are greatest for federal government workers.

The sectoral differences among the various compensation measures are striking. However, one must be cautious in interpreting them, given that workers' characteristics might "explain" these differences. Table 2 shows weighted means and standard deviations of the key demographic variables for workers in the private sector and various levels of government. The figures indicate that, indeed, worker characteristics differ substantially across sectors. For example, on average, government employees at all levels have more education than private sector employees, which gives some credence to the notion that the compensation differentials in Table 1 might be due to differences in human capital.

In this context, an important question is whether our analysis sample is plausibly nationally representative (conditional on the screens used to generate it). The issue is cogent because the 2006 survey does not have many of the respondents included when the HRS was started as a nationally representative data set of individuals who were 51 to 61 years of age in 1992. This is an empirical issue, and a sensible way to approach it is to apply to a nationally representative data set the same screens that we use to generate our HRS analysis sample, and compare summary statistics of the key variables that are available in both samples. To that end, we took the 2006 CPS, applied the screens as with the HRS, computed the relevant (weighted) summary statistics, and compared them to the HRS. The results, available upon request, indicate that the summary statistics for the two samples are 
quite close. Indeed, for none of the variables can one reject the hypothesis that the respective HRS and CPS means are equal.

Table 2. variable definitions and summary statistics*

\begin{tabular}{|c|c|c|c|c|c|}
\hline Variable & Description & $\begin{array}{l}\text { Private } \\
\text { Sector }\end{array}$ & $\begin{array}{c}\text { Federal } \\
\text { Government }\end{array}$ & $\begin{array}{c}\text { State } \\
\text { Government }\end{array}$ & $\begin{array}{c}\text { Local } \\
\text { Government }\end{array}$ \\
\hline NoDegree & $\begin{array}{l}\text { Omitted Category: } 1 \text { if the } \\
\text { respondent did not complete high } \\
\text { school }\end{array}$ & $\begin{array}{c}0.090 \\
(0.286)\end{array}$ & $\begin{array}{c}0.016 \\
(0.125)\end{array}$ & $\begin{array}{c}0.031 \\
(0.173)\end{array}$ & $\begin{array}{c}0.043 \\
(0.202)\end{array}$ \\
\hline GED & $\begin{array}{c}1 \text { if the respondent's highest } \\
\text { degree is a GED }\end{array}$ & $\begin{array}{c}0.044 \\
(0.204)\end{array}$ & $\begin{array}{c}0.010 \\
(0.099)\end{array}$ & $\begin{array}{c}0.032 \\
(0.177)\end{array}$ & $\begin{array}{c}0.030 \\
(0.172)\end{array}$ \\
\hline$H S$ & $\begin{array}{l}1 \text { if the respondent's highest } \\
\text { degree is a high school degree }\end{array}$ & $\begin{array}{c}0.517 \\
(0.500)\end{array}$ & $\begin{array}{c}0.438 \\
(0.498)\end{array}$ & $\begin{array}{c}0.359 \\
(0.481)\end{array}$ & $\begin{array}{c}0.397 \\
(0.490)\end{array}$ \\
\hline TwoCollege & $\begin{array}{l}1 \text { if the respondent's highest } \\
\text { degree is a } 2 \text {-year college degree }\end{array}$ & $\begin{array}{c}0.082 \\
(0.274)\end{array}$ & $\begin{array}{c}0.100 \\
(0.301)\end{array}$ & $\begin{array}{c}0.045 \\
(0.209)\end{array}$ & $\begin{array}{c}0.073 \\
(0.260)\end{array}$ \\
\hline FourCollege & $\begin{array}{l}1 \text { if the respondent's highest } \\
\text { degree is a 4-year college degree }\end{array}$ & $\begin{array}{c}0.170 \\
(0.376)\end{array}$ & $\begin{array}{c}0.189 \\
(0.393)\end{array}$ & $\begin{array}{c}0.206 \\
(0.406)\end{array}$ & $\begin{array}{c}0.185 \\
(0.389)\end{array}$ \\
\hline Masters & $\begin{array}{l}1 \text { if the respondent's highest } \\
\text { degree is a masters degree }\end{array}$ & $\begin{array}{c}0.078 \\
(0.268)\end{array}$ & $\begin{array}{c}0.198 \\
(0.400)\end{array}$ & $\begin{array}{c}0.167 \\
(0.374)\end{array}$ & $\begin{array}{c}0.239 \\
(0.427)\end{array}$ \\
\hline Professional & $\begin{array}{l}1 \text { if the respondent's highest } \\
\text { degree is a professional degree }\end{array}$ & $\begin{array}{c}0.021 \\
(0.142)\end{array}$ & $\begin{array}{c}0.050 \\
(0.219)\end{array}$ & $\begin{array}{c}0.159 \\
(0.367)\end{array}$ & $\begin{array}{c}0.035 \\
(0.183)\end{array}$ \\
\hline Black & 1 if the respondent is black & $\begin{array}{c}0.080 \\
(0.272)\end{array}$ & $\begin{array}{c}0.146 \\
(0.355)\end{array}$ & $\begin{array}{c}0.138 \\
(0.346)\end{array}$ & $\begin{array}{c}0.096 \\
(0.295)\end{array}$ \\
\hline Female & 1 if the respondent is female & $\begin{array}{c}0.464 \\
(0.499)\end{array}$ & $\begin{array}{c}0.492 \\
(0.502)\end{array}$ & $\begin{array}{c}0.605 \\
(0.490)\end{array}$ & $\begin{array}{c}0.468 \\
(0.500)\end{array}$ \\
\hline Married & 1 if the respondent is married & $\begin{array}{c}0.674 \\
(0.469)\end{array}$ & $\begin{array}{c}0.670 \\
(0.472)\end{array}$ & $\begin{array}{c}0.726 \\
(0.447)\end{array}$ & $\begin{array}{c}0.678 \\
(0.468)\end{array}$ \\
\hline Age & Age of respondent in years & $\begin{array}{c}58.17 \\
(4.596)\end{array}$ & $\begin{array}{c}58.82 \\
(4.600)\end{array}$ & $\begin{array}{c}58.21 \\
(4.048)\end{array}$ & $\begin{array}{c}58.10 \\
(4.780)\end{array}$ \\
\hline $\mathrm{Age}^{2}$ & Age squared & $\begin{array}{c}3404.4 \\
(564.13)\end{array}$ & $\begin{array}{c}3480.8 \\
(567.15)\end{array}$ & $\begin{array}{c}3404.6 \\
(487.69)\end{array}$ & $\begin{array}{c}3397.8 \\
(587.67)\end{array}$ \\
\hline Urban & $\begin{array}{c}1 \text { if the respondent lives in metro } \\
\text { area of } 1 \text { million or more } \\
\text { population }\end{array}$ & $\begin{array}{c}0.452 \\
(0.498)\end{array}$ & $\begin{array}{c}0.416 \\
(0.495)\end{array}$ & $\begin{array}{c}0.340 \\
(0.475)\end{array}$ & $\begin{array}{c}0.436 \\
(0.497)\end{array}$ \\
\hline Suburban & $\begin{array}{c}1 \text { if the respondent lives in metro } \\
\text { area of } 250,000 \text { to } 1 \text { million } \\
\text { population }\end{array}$ & $\begin{array}{c}0.266 \\
(0.442)\end{array}$ & $\begin{array}{c}0.311 \\
(0.465)\end{array}$ & $\begin{array}{c}0.250 \\
(0.432)\end{array}$ & $\begin{array}{c}0.210 \\
(0.408)\end{array}$ \\
\hline Ex-Urban & $\begin{array}{l}\text { Omitted Category: } 1 \text { if the } \\
\text { respondent lives in area of less } \\
\text { than } 250,000 \text { population }\end{array}$ & $\begin{array}{c}0.282 \\
(0.450)\end{array}$ & $\begin{array}{c}0.273 \\
(0.447)\end{array}$ & $\begin{array}{c}0.413 \\
(0.493)\end{array}$ & $\begin{array}{c}0.354 \\
(0.479)\end{array}$ \\
\hline
\end{tabular}

*This table shows means and standard deviations for independent variables by employment sector, weighted by 2006 respondent weights. The maximal number of respondents with non-zero sample weights is 1,907 for the private sector, 115 for federal government, 225 for state government, and 249 for local government. These figures are the same across all variables. 


\section{Econometric Specification and Results}

While informative, the figures in Table 1 are only suggestive because they fail to account for the fact that employee characteristics differ substantially across sectors. This section presents the results from multivariate models. (Note 16)

\subsection{Hourly Wages}

Basic setup. To begin, we estimate regressions of the log of hourly pay (LOG(WAGE)) on worker characteristics and dichotomous variables for sector of employment. Specifically, we regress the logarithm of the hourly wage on a set of indicators for sector of employment (with the private sector as the excluded category) as well as educational attainment, gender, race, marital status, and a quadratic in age. (Note 17, 18) In effect, this specification constrains all the coefficients, except those on the sectoral variables, to be the same across sectors. A more flexible approach, suggested by Blinder (1973) and Oaxaca (1973), allows all the coefficients to vary across sectors. We choose the more constrained model because it generates essentially the same results as the Blinder-Oaxaca approach and is simpler to exposit.

Unlike some previous studies, we do not include occupational variables in our canonical model. As Gittleman and Pierce (2012, p. 227) point out, there is no consensus on this matter. We choose not to include occupation, because occupational choice could very well be jointly determined with wages and it is available only for a subset of our sample. (Note 19) However, as shown in Section 5, when we include occupation on the right hand side, the results are nearly identical.

Table 3. Hourly compensation*

\begin{tabular}{|c|c|c|c|c|}
\hline Variable & $\begin{array}{c}\mathbf{1}) \\
\log (W A G E)\end{array}$ & $\begin{array}{c}\text { (2) } \\
\log (W A G E)\end{array}$ & $\begin{array}{c}\text { (3) } \\
\log (W A G E+D C)\end{array}$ & $\begin{array}{c}\text { (4) } \\
\log (W A G E+D C)\end{array}$ \\
\hline Federal & $\begin{array}{c}0.371 * * * \\
(0.052)\end{array}$ & $\begin{array}{c}0.278 * * * \\
(0.045)\end{array}$ & $\begin{array}{l}0.373 * * * \\
(0.0523)\end{array}$ & $\begin{array}{l}0.277 * * * \\
(0.0464)\end{array}$ \\
\hline State & $\begin{array}{c}0.163 * * * \\
(0.046)\end{array}$ & $\begin{array}{c}0.0559 \\
(0.0414)\end{array}$ & $\begin{array}{l}0.152 * * * \\
(0.0466)\end{array}$ & $\begin{array}{c}0.0379 \\
(0.0418)\end{array}$ \\
\hline Local & $\begin{array}{l}0.086^{* *} \\
(0.037)\end{array}$ & $\begin{array}{l}-0.0134 \\
(0.0333)\end{array}$ & $\begin{array}{l}0.0673 * \\
(0.0372)\end{array}$ & $\begin{array}{l}-0.0339 \\
(0.0338)\end{array}$ \\
\hline GED & & $\begin{array}{l}0.122 * * * \\
(0.0394)\end{array}$ & & $\begin{array}{l}0.138^{* *} \\
(0.0431)\end{array}$ \\
\hline$H S$ & & $\begin{array}{l}0.318 * * * \\
(0.0279)\end{array}$ & & $\begin{array}{l}0.328 * * * \\
(0.0283)\end{array}$ \\
\hline TwoCollege & & $\begin{array}{l}0.425 * * * \\
(0.0455)\end{array}$ & & $\begin{array}{l}0.435 * * * \\
(0.0461)\end{array}$ \\
\hline FourCollege & & $\begin{array}{l}0.639 * * * \\
(0.0434)\end{array}$ & & $\begin{array}{l}0.649 * * * \\
(0.0443)\end{array}$ \\
\hline Masters & & $\begin{array}{l}0.819^{* * *} \\
(0.0525)\end{array}$ & & $\begin{array}{c}0.835^{* * *} \\
(0.054)\end{array}$ \\
\hline Professional & & $\begin{array}{l}1.000^{* * *} \\
(0.0525)\end{array}$ & & $\begin{array}{l}1.05^{* * *} \\
(0.067)\end{array}$ \\
\hline Black & & $\begin{array}{c}-0.183^{* * *} \\
(0.0314)\end{array}$ & & $\begin{array}{c}-0.180^{* * *} \\
(0.034)\end{array}$ \\
\hline
\end{tabular}


Female

Married

Age

$\operatorname{Age}^{2}$

Urban

Suburban

Constant

(0.018)
$-0.190 * * *$

(0.0197)

$0.0758 * *$

(0.0181)

0.0174

(0.066)

$-0.000177$

(0.000537)

$0.239 * * *$

(0.0311)

$0.0828 * * *$

(0.0304)

2.048

(2.017)
$-0.190 * * *$

$0.0789 * *$

(0.0182)

0.0219

$-0.000216$

(0.000537)

$0.0904 * * *$

(0.0306)

(0.0183)

Observations

2,496

2,496

2,496

* Estimation is by ordinary least squares. The right-hand side variables are defined in Table 2. Standard errors are in parentheses. A $(* * *)$ indicates that the variable is statistically significant at the 1 percent level, a $(* *)$ at the 5 percent level, and a $(*)$ at the 10 percent level.

Results. The estimates are reported in Table 3. The first column shows the results when only the sectoral variables are included. Substantial positive differentials are present for all government levels: federal government employees earn approximately 37.1 log points more than private sector employees, state government employees earn 16.3 log points more, and local government employees earn 8.6 log points more.

The estimates in column (2) take employee characteristics into account. The federal-private differential falls to 0.278 (s.e. $=0.045$ ), considerably smaller than the corresponding figure in column (1), but still significantly different from zero. In contrast, the state and local government differentials are generally rendered small and statistically insignificant when worker characteristics are included in the model. Taken together, the results in columns (1) and (2) are consistent with the claim that it can be misleading to look at public-private wage differences without taking into account worker characteristics. Our finding of a large and statistically significant federal differential is generally in line with previous results, most notably by Smith (1976a, 1976b, 1977), Venti (1987), Krueger (1988), and Moore and Raisian (1991). However, our point estimate is somewhat larger than theirs. This raises the question of whether our finding is idiosyncratic to the HRS dataset. To investigate this possibility, we applied to the CPS the same screens as we used to generate our analysis sample, and then replicated the specification in column (2) as closely as we could. The results, in an appendix available upon request, indicate that the estimated federal differential using the CPS is somewhat smaller than our estimate in Table 3, but one cannot reject the hypothesis that they are equal. Thus, our estimate of the federal hourly earnings differential does not appear to be an artifact of the HRS sample. The signs and magnitudes of the coefficients on the other covariates are sensible and in line with the results of previous econometric work on wage determination.

\subsection{Hourly Wages and Employer Contributions to DC Plans}

We now turn to differences in compensation that come in the form of pensions. (Note 20) Integrating employer contributions to defined contribution plans with wages is fairly straightforward. (We return later to issues associated with incorporating defined benefit plans.) We create a variable, $W A G E+D C$, which equals the sum of the (hourly) dollar amount of employer DC pension contributions (if any) (Note 21) and hourly pay. The last two columns in Table 3 show the results when we use our standard earnings function to analyze this broader measure of compensation. Comparing column (1) to column (3) suggests that including employer contributions to DC plans has little effect on the raw sectoral coefficients. The results after taking demographic characteristics into 
account (columns (2) and (4)) are also very similar. Thus, incorporating employers' DC contributions into the analysis does not substantively change the results one obtains by looking at wages only.

\subsection{Pension Wealth}

So far, our focus has been on flows of compensation associated with wages and employer contributions to DC plans. In principle, one would also want to include the incremental accrued value of employer contributions to defined benefit plans during the relevant time period, which is also a flow. Such a variable is not included in the public version of the HRS data. However, Gustman, Steinmeier, and Tabatabai (2010) calculate a useful stock measure, total pension wealth. It is defined as the sum of the present value of future benefits from a worker's most important DB plan on the current job and the cash balances in all DC plans on the current job, based on work to date.

This section examines how total pension wealth depends on sector of employment. As previously noted, just like wages, pension wealth likely depends on an employee's personal characteristics. Hence, a multivariate approach is needed to ascertain the independent effect of sector of employment upon pension wealth. We include the same set of right hand side variables as in the wage regressions.

Table 4. Pension wealth differentials*

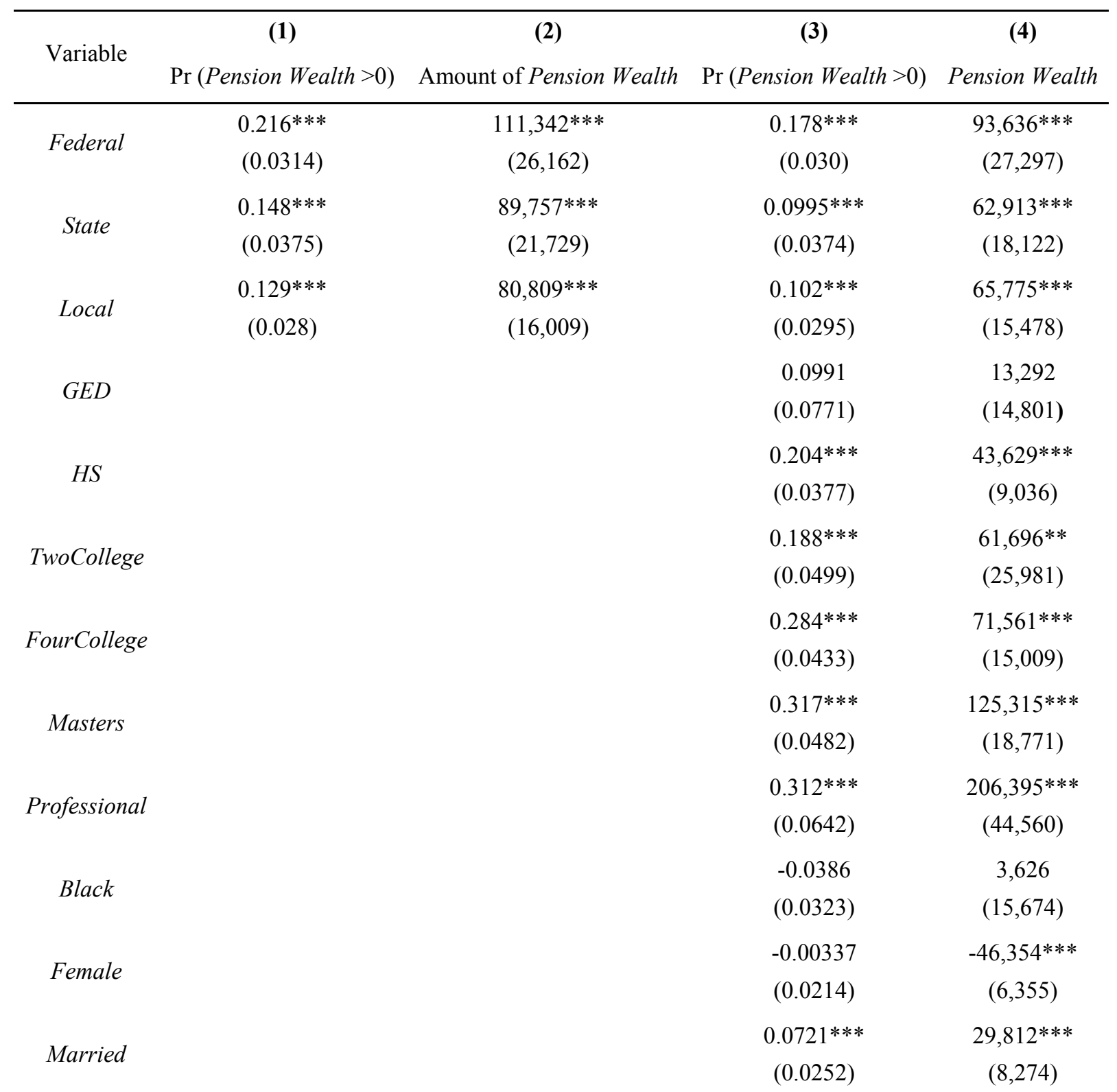




\begin{tabular}{|c|c|c|c|c|}
\hline Age & & & $\begin{array}{c}0.179 * * * \\
(0.0282)\end{array}$ & $\begin{array}{c}26,957 * * \\
(11,427)\end{array}$ \\
\hline$A g e^{2}$ & & & $\begin{array}{c}-0.00157^{* * *} \\
(0.000228)\end{array}$ & $\begin{array}{c}-247.0 * * * \\
(92.9)\end{array}$ \\
\hline Urban & & & $\begin{array}{c}0.0199 \\
(0.0214)\end{array}$ & $\begin{array}{c}32,398 * * * \\
(10,174)\end{array}$ \\
\hline Suburban & & & $\begin{array}{l}0.0356 \\
(0.024)\end{array}$ & $\begin{array}{c}17,717^{*} \\
(9,764)\end{array}$ \\
\hline Constant & $\begin{array}{c}0.727^{* * *} \\
(0.0139)\end{array}$ & $\begin{array}{c}82,490 * * * \\
(5,639)\end{array}$ & $\begin{array}{c}-4.604^{* * *} \\
(0.864)\end{array}$ & $\begin{array}{c}-720,121^{*} \\
(349,683)\end{array}$ \\
\hline bservations & 2,100 & 2,100 & 2,100 & 2,100 \\
\hline
\end{tabular}

* Columns (1) and (3) provide estimates of the marginal effects on the probability that the respondent has positive pension wealth, based on linear probability models. Columns (2) and (4) are the corresponding OLS estimates of the effects on the amount of pension wealth. The right-hand side variables are defined in Table 2 . Standard errors are in parentheses. A $(* * *)$ indicates that the variable is statistically significant at the 1 percent level, a (**) at the 5 percent level, and a $(*)$ at the 10 percent level.

Column (1) of Table 4 shows the estimates from a linear probability model of the impact of sector of employment on the probability of having positive pension wealth without any additional covariates. Compared to private sector employees, federal workers are 21.6 percentage points more likely to have positive pension wealth, state workers are 14.8 percentage points more likely, and local workers are 12.9 percentage points more likely. All the coefficients are statistically significant. The corresponding pension wealth differentials are in column (2). Workers in all government sectors have more pension wealth than their private sector counterparts: on average, federal workers have $\$ 111,000$ more pension wealth, state workers have $\$ 89,800$ more, and local workers have $\$ 80,800$ more.

Columns (3) and (4) include our other covariates. The most striking result is that the uncorrected pension wealth differentials from column (2) are reduced yet remain substantial and statistically significant. Specifically, column (4) shows federal, state and local pension differentials of $\$ 93,600, \$ 62,900$, and $\$ 65,800$, respectively. Because wages are a flow variables and pension wealth is a stock variable, the results from Tables 3 and 4 are not directly comparable. To allow comparisons, we begin by computing the hourly annuity value of the pension wealth differential in each government sector. Suppose that the pension wealth differential in sector $s$ is $D_{s}$. Suppose further that the average number of years of service for workers in that sector is $T_{s}$. Then we compute the annuity value of $D_{s}$ over $T_{s}$ years, assuming an interest rate of 5.8 percent, the rate used by Gustman, Steinmeier, and Tabatabai (2010) in their calculations. (Note 22)

The mean years of service with the current employer for our 2004 pension wealth subsample (Note 23) are: 13.1 for private sector workers, 17.1 for federal workers, 14.0 for state workers, and 16.4 for local workers. Using these values and the respective pension wealth differentials from Table 4 , the annuitized differentials are $\$ 8,778$, $\$ 6,685$ and $\$ 6,323$ for federal, state, and local workers, respectively. The mean yearly number of hours worked for our pension wealth sample in 2006 is 2,256 for private sector workers, 2,192 for federal workers, 2,148 for state workers, and 2,156 for local workers. Therefore, the annuitized pension wealth differentials per hour come to $\$ 4.00, \$ 3.11$ and $\$ 2.93$ for federal, state, and local workers, respectively. As a proportion of the hourly private-sector wage, these amount to 17.2 percent, 13.4 percent, and 12.6 percent for federal, state, and local workers, respectively.

\subsection{Preliminary Conclusions}

Summary. Taken together, this section's results suggest that once differences in worker characteristics are taken into account, there are no statistically significant differences in hourly wages between state and local workers and their private sector counterparts. There is, however, a substantial wage differential for federal workers, ceteris paribus, of about 28 percent. In addition, employees of all levels of government generally have substantially more pension wealth than their private sector counterparts. 
Toward a comprehensive measure of compensation differentials. One way to generate comprehensive compensation differentials would be to take the sum of our hourly equivalent pension wealth differentials and the wage differentials from the second column of Table 3. (Note 24) However, doing so could be misleading; seeing why brings us to the next complication in interpreting the pension wealth differentials. Suppose that a given individual's DB pension is funded entirely by her own contributions; the employer puts in nothing. In that case, pension wealth would not represent any additional compensation; it would just be a use to which the individual puts her wages. Hence, it would be inappropriate to add the pension wealth and wage differentials to obtain a total compensation differential.

More generally, as long as a portion of contributions to DB pension plans comes from employees, then to some extent double-counting will occur if one simply adds the wage and pension differentials. This observation immediately leads to the question of how much pension wealth is due to employer and to employee contributions, respectively. Our data do not provide an answer. However, using information from several sources, a back-of-the-envelope estimate is possible. The steps in this calculation are as follows:

First, obtain an estimate of the average hourly amount of DC contributions made by employers and employees in each sector. As noted in Section 3, this information is available in the HRS data.

Second, obtain an estimate of the hourly amount of DB contributions made by employers and employees. The HRS data do not have this information. However, Bureau of Labor Statistics data allow us to make a rough imputation. Specifically, BLS data report the average hourly employer cost for state and local workers' DB plans (\$2.27 in 2006) (Note 25) and the average required employee contribution rate for state and local workers' DB plans (6.3 percent in 2007) (Note 26). Given that the average required employee DB contribution rate is computed only over the set of state and local employees with DB plans requiring an employee contribution, we multiply the 6.3 percent figure by the percentage of DB plans that require a contribution (77 percent in 2007) (Note 27), which yields an average employee contribution rate of 4.85 percent across all workers. For federal workers, the website of the Office of Personnel Management indicates that the contribution rate is 7.0, 7.5 or 8.0 percent for both employers and employees; we use 7.5 percent, the midpoint of this range (Note 28). By multiplying the employee's average required DB contribution rate with the mean hourly wages listed in Table 1 and the average number of DB plans per worker in each sector in our sample, we calculate hourly employee DB contributions of $\$ 1.60$ for federal workers, $\$ 1.55$ for state workers, and $\$ 0.89$ for local workers.

Third, multiply our respective estimated hourly pension wealth differentials by the ratio of the sum of the employer DC and DB contributions to the sum of employer and employee DC and DB contributions. This yields a set of differentials due to employer contributions. An appendix available upon request provides details.

The last step is to add these figures to the wage differentials from column (2) of Table 3. Given that one cannot reject the hypothesis that the state and local differentials are zero, for this purpose we simply treat them as zero. This yields total compensation differentials of 34.2 percent for federal employees (Note 29), 7.49 percent for state employees, and 8.29 percent for local employees.

\section{Alternative Specifications}

In order to assess the robustness of our results, in this section we estimate several alternate specifications of the basic model.

\subsection{Differential Effects by Education}

In our model, sectoral compensation differentials are independent of education. This specification runs counter to longstanding concerns that because of inflexibilities in government pay schedules, highly educated public sector workers earn less than their private sector counterparts. (Note 30) We explore this hypothesis by augmenting our basic model with interaction terms between the sectoral dichotomous variables and a binary variable, CollegePlus, which equals one if a worker has a four-year college or higher degree, and zero otherwise. We report here only the key results. In the equation for $W A G E+\mathrm{DC}$, the interactions of the sectoral dichotomous variables with CollegePlus are all statistically insignificant. For pension wealth, the interaction term between STATE and CollegePlus is positive and significant at $\$ 75,820$ (s.e. $=\$ 27,906$ ), while the other two sectoral interaction terms are insignificant. Thus, we find no evidence in our data that highly educated workers are disadvantaged by working in the public sector. 


\title{
5.2 Controlling for Occupation
}

Table 5. Hourly Wages plus DC Contributions, Controlling for Occupation (Dependent Variable is Log of $(W A G E+D C))^{*}$

(1)

Variable (no occupation controls; no other covariates)
(2)

(3)

\begin{tabular}{cccc} 
Variable & $\begin{array}{c}\text { (no occupation controls; no } \\
\text { other covariates) }\end{array}$ & $\begin{array}{c}\text { (no occupation controls; } \\
\text { same covariates as in Table }\end{array}$ & $\begin{array}{c}\text { (occupation controls; } \\
\text { same covariates as in } \\
\text { Table 3) }\end{array}$ \\
\hline Federal & $0.485^{* * *}$ & $3)$ & $0.265^{* * *}$ \\
State & $(0.0713)$ & $0.302^{* * *}$ & $(0.0618)$ \\
& $0.197^{* * *}$ & $(0.0647)$ & 0.0821 \\
Local & $(0.0518)$ & 0.0398 & $(0.0503)$ \\
& $0.0739^{* * *}$ & $(0.0511)$ & 0.0316 \\
Observations & $(0.0513)$ & -0.0389 & $(0.0480)$ \\
& 1,453 & $(0.0498)$ & 1,453
\end{tabular}

\begin{abstract}
* This table augments the model of Table 3 with a set of dichotomous variables for occupation. The number of observations differs from that of the basic sample $(2,946)$ because not every respondent provided information about occupation. The other right-hand side variables are the same as in Table 3, but not reported here. Standard errors are in parentheses. A $\left({ }^{* * *}\right)$ indicates that the variable is statistically significant at the 1 percent level, a $(* *)$ at the 5 percent level, and a $(*)$ at the 10 percent level.
\end{abstract}

We chose not to include controls for occupation in our basic model because of concerns that it might be jointly determined with compensation. In addition, in our data, occupation is reported for only 1,453 observations, considerably fewer than the 2,496 used to generate the estimates in Table 3. Nevertheless, it is of some interest to see if our results change qualitatively when we augment the model with a set of dichotomous variables designating occupational categories. (Note 31) Table 5 displays the results for the logarithm of $(W A G E+D C)$. In columns (1) and (2) we establish a baseline by using the smaller sample to estimate the models from the last two columns of Table 3, and then add the occupation variables in column (3). Only the coefficients on the sectoral variables are reported. The coefficients in columns (1) and (2), while having somewhat different magnitudes, are qualitatively similar to their counterparts in Table 3. Once occupation controls are added in column (3), the implied federal differentials falls slightly and remains statistically significant. The point estimate, 0.265 , is virtually the same as the corresponding figure in Table 3,0.277. The state and local differentials remain statistically insignificant, also just as they were in Table 3. In short, our substantive results are essentially unchanged when controls for occupation are included. (Note 32)

\section{Conclusion}

We have used a sample of older full-time workers from the 2006 Health and Retirement Study to study wage and pension compensation differentials between government and private sector employees. With respect to hourly wages (including employee contributions to defined contribution plans), federal workers earn a premium of about 28 log points. However, no statistically significant differences for state and local workers emerge once employee characteristics are taken into account. Workers at all levels of government accumulate more pension wealth than private sector workers, even after holding employee characteristics constant. Specifically, as a proportion of the hourly private-sector wage, the hourly equivalent public-private differentials are about 17.2 percent, 13.4 percent and 12.6 percent at the federal, state, and local levels, respectively. Our results offer some support to both sides in the rather noisy public debate over public sector compensation. The argument that taking worker characteristics into account can make a big difference in public-private comparisons is correct. However, those who assert that examining wages alone can be misleading are also right. Once pension benefits are taken 
into account, employees at all levels of government receive higher compensation than private sector workers, and these differentials cannot be explained away by differences in worker characteristics.

As usual, one must be cautious in interpreting compensation differences. They might be due to compensating differentials associated with unobserved job characteristics, or they might arise from successful rent-seeking. An important subject for future research is to determine the source of these unexplained differences. Further, it would be interesting to apply the methods used in this paper to a sample that includes a larger proportion of younger workers, if a data set with all the requisite variables were to become available. Integrating information on the value of other benefits (such as employer-provided health insurance) with wage and pension differentials within a micro data framework is another important topic for future research.

\section{Acknowledgements}

We are grateful to Orley Ashenfelter, Bobray Bordelon, Henry Farber, Daniel Feenberg, Alexis Furuichi, Michael Geruso, Alan Gustman, Yan Lau, Jonathan Meer, Olivia Mitchell, Ulrich Mueller, Linda Oppenheim, Nahid Tabatabai, Oscar Torres, Mark Watson, Madeline Young, and seminar participants at the University of Uppsala and Texas A\&M University for useful comments. Support from Princeton's Griswold Center for Economic Policy Studies is gratefully acknowledged.

\section{References}

Allegretto, S. A., \& Keefe, J. (2010, October). The truth about public employees in California: They are neither overpaid nor overcompensated. Center on Wage and Employment Dynamics Policy Brief, Institute for Research on Labor and Employment, University of California, Berkeley. Retrieved from http://www.irle.berkeley.edu/cwed/wp/2010-03.pdf

Altonji, J. G., \& Williams, N. (2005). Do wages rise with job seniority? A reassessment. Industrial and Labor Relations Review, 58(3), 370-397.

Belman, D., \& Heywood, J. S. (1995). State and local government wage differentials: An intrastate analysis. Journal of Labor Research, 16(2), 187-201. http://dx.doi.org/10.1007/BF02685740

Bender, K. A., \& Heywood, J. S. (2010, April). Out of balance? Comparing public and private sector compensation over 20 years. National Institute on Retirement Security and Center for State and Local Government Excellence Report. Retrieved from http://www.nirsonline.org/storage/nirs/documents/final_out_of_balance_report_april_2010.pdf

Blackburn, M. L. (2008). Are union wage differentials in the United States falling? Industrial Relations, 47(3), 390-418. http://dx.doi.org/10.1111/j.1468-232X.2008.00526.x

Blinder, A. S. (1973). Wage discrimination: Reduced form and structural estimates. Journal of Human Resources, 8(4), 436-455. http://dx.doi.org/10.2307/144855

Blue Mass Group. (2011, March 7). A reality check on compensation for public employees. Retrieved from $\mathrm{http} / / /$ bluemassgroup.com/2011/03/a-reality-check-on-compensation-for-public-employees

Cannon, A. (2011, February 3). Apples to apples: Private-sector and public-sector compensation in Iowa. Iowa Policy Project Report. Retrieved from http://iowapolicyproject.org/2011docs/110222-pubpvtpay.pdf

Christie, C. (2010, March 5). We have no choice. New York Post. Retrieved from http://nypost.com/2010/03/05/we-have-no-choice/

Clark, R. L., Craig, L. A., \& Ahmed, N. (2009). The evolution of public-sector pension plans in the United States. In O. S. Mitchell \& G. Anderson (Eds.), the future of public employee retirement systems (pp. 239-270). New York, NY: Oxford University Press. http://dx.doi.org/10.1093/acprof:oso/9780199573349.003.0014

Congressional Budget Office. (2002, November 1). Measuring differences between federal and private pay. Retrieved from http://www.cbo.gov/publication/14214

Congressional Budget Office. (2012, January). Comparing the compensation of federal and private-sector employees. Retrieved from http://www.cbo.gov/publication/42921

Cook, G. (2011, March 6). Bluster surrounds debate over salaries, benefits. Las Vegas Review-Journal. Retrieved

from http://www.reviewjournal.com/news/government/bluster-surrounds-debate-over-salaries-benefits 
Delaney, A. (2011, February 25). Are these people overpaid? Huff Post Business. Retrieved from http://www.huffingtonpost.com/2011/02/25/wisconsin-workers-overpaid_n_828077.html

Garofalo, P. (2010, June 7). Gov. Daniels bashes public employees as "a new privileged class." Think Progress. Retrieved from http://thinkprogress.org/economy/2010/06/07/173307/daniels-public-pay/

Gittleman, M., \& Pierce, B. (2012). Compensation for state and local government workers. Journal of Economic Perspectives, 26(1), 217-242. http://dx.doi.org/10.1257/jep.26.1.217

Gustman, A. L., Steinmeier, T. L., \& Tabatabai, N. (2010). Pensions in the Health and Retirement Study. Cambridge, MA: Harvard University Press.

Gustman, A. L., Steinmeier, T. L., \& Tabatabai, N. (2013). Redistribution under the Social Security benefit formula at the individual and household levels, 1992 and 2004. Journal of Pension Economics and Finance, 12(1), 1-27. http://dx.doi.org/10.1017/S1474747212000108

Gyourko, J., \& Tracy, J. (1988). An analysis of public- and private-sector wages allowing for endogenous choices of both government and union status. Journal of Labor Economics, 6(2), 229-253. http://dx.doi.org/10.1086/298182

Health and Retirement Study. (2006, December). Imputations for pension wealth data description and usage (version 2.0). Produced and distributed by the University of Michigan with funding from the National Institute on Aging (grant number NIA U01AG009740), Ann Arbor, MI. Retrieved from http://hrsonline.isr.umich.edu/modules/meta/xyear/ipw/desc/imppenwdd.pdf

Health and Retirement Study. (2008, December). Sample evolution: 1992-1998 survey design. Produced and distributed by the University of Michigan with funding from the National Institute on Aging (grant number NIA U01AG009740), Ann Arbor, MI. Retrieved from http://hrsonline.isr.umich.edu/sitedocs/surveydesign.pdf

Keefe, J. (2010, September). Debunking the myth of the overcompensated public employee. Economics Policy Institute Briefing Paper $276 . \quad$ No. Retrieved from http://www.epi.org/publication/debunking_the_myth_of_the_overcompensated_public_employee/

Krueger, A. B. (1988). Are public sector workers paid more than their alternative wage? Evidence from longitudinal data and job queues. In R. B. Freeman, \& C. Ichniowsk (Eds.), When Public Sector Workers Unionize (pp. 217-242). Chicago, IL: University of Chicago Press.

Krugman, P. (2010, December 2). Freezing out hope. The New York Times. Retrieved from http://www.nytimes.com/2010/12/03/opinion/03krugman.html?_r=0

Lewis, G. B., \& Galloway, C. S. (2011, February). A national analysis of public/private wage differentials at the state and local levels by race and gender. Andrew Young School of Policy Studies Research Paper No. 11-10, Georgia State University, Atlanta, GA.

Moore, W. J., \& Raisian, J. (1991). Government wage differentials revisited. Journal of Labor Research, 12(1), 13-33. http://dx.doi.org/10.1007/BF02685367

Mulvihill, G. (2011, March 8). Political battles playing out in state capitals. HuffPost Politics. Retrieved from http://www.huffingtonpost.com/2011/03/08/government-worker-benefit_n_832777.html

Munnell, A. H., \& Perun, P. (2006, August). An update on private pensions. Center for Retirement Research at Boston College Issue in Brief No. 50. Retrieved from http://crr.bc.edu/wp-content/uploads/2013/05/SLP31.pdf

Oaxaca, R. (1973). Male-female wage differentials in urban labor markets. International Economic Review, 14(3), 693-709. http://dx.doi.org/10.2307/2525981

Quinn, J. F. (1979). Wage differentials among older workers in the public and private sectors. The Journal of Human Resources, 14(1), 41-62. http://dx.doi.org/10.2307/145537

Quinn, J. F. (1982). Pension Wealth of Government and Private Sector Workers. The American Economic Review, 72(2), 283-287.

Ramoni-Perazzi, J., \& Bellante, D. (2007). Do truly comparable public and private sector workers show any compensation differential? Journal of Labor Research, 28(1), 117-133. 
Schmitt, J. (2010, May). The wage penalty for state and local government employees. Center for Economic and Policy Research Report. Retrieved from http://www.cepr.net/documents/publications/wage-penalty-2010-05.pdf

Smith, S. P. (1976a). Pay differentials between federal government and private sector workers. Industrial and Labor Relations Review, 29(2), 179-197. http://dx.doi.org/10.2307/2522140

Smith, S. P. (1976b). Government wage differentials by sex. The Journal of Human Resources, 11(2), 185-199. http://dx.doi.org/10.2307/145452

Smith, S. P. (1977). Government wage differentials. Journal of Urban Economics, 4(3), 248-271. http://dx.doi.org/10.1016/0094-1190(77)90011-0

Thompson, J., \& Schmitt, J. (2010, September). The wage penalty for state and local government employees in New England. Political Economy Research Institute and Center for Economic and Policy Research Joint Working Paper No. 232, University of Massachusetts, Amherst, MA and Washington, D.C. Retrieved from http://www.peri.umass.edu/fileadmin/pdf/working_papers/working_papers_201-250/WP233.pdf

Tuutti, C. (2010, March 10). Federal employees not overpaid, Says OMB Chief Peter R. Orszag. Executive Gov. Retrieved from $\mathrm{http} / / /$ www.executivegov.com/2010/03/federal-employees-not-overpaid-says-omb-chief-peter-r-orszag/

U.S. Bureau of Labor Statistics. (2006, June). Employer costs for employee compensation-March 2006. Retrieved from http://www.bls.gov/news.release/archives/ecec_06212006.pdf

U.S. Bureau of Labor Statistics. (2008, March). National compensation survey: Employee benefits in state and local governments in the United States-September 2007. Retrieved from http://www.bls.gov/ncs/ebs/sp/ebsm0007.pdf

U.S. Office of Personnel Management. Civil Service Retirement System (CSRS) information. Retrieved from http://www.opm.gov/retirement-services/csrs-information/

Venti, S. F. (1987). Wages in the federal and private sectors. In D. A. Wise (Ed.), Public Sector Payrolls (pp. 147-182). Chicago, IL: University of Chicago Press.

\section{Notes}

Note 1. In 2006, the year that we study, 70.1 percent of compensation came in the form of wages and salaries. Another 9.5 percent consisted of monetary compensation such as paid vacations and overtime pay. Contributions to defined benefit and defined contribution retirement saving plans were 4.3 percent. For further details on the composition of compensation see U.S. Bureau of Labor Statistics (2006).

Note 2. See Quinn (1979), Gyourko and Tracy (1988), Venti (1987), and Moore and Raisin (1991).

Note 3. See Krueger (1988).

Note 4. See Belman and Heywood (1995), Schmitt (2010), and Lewis and Galloway (2011).

Note 5. Hence, the opposite characterization of the literature by Peter Orszag (Tuutti, 2010) and Paul Krugman (2010) seems rather curious.

Note 6 . This calculation includes fringe benefits other than pensions, such as sick leave, paid vacation, and the value of differences in unemployment probabilities.

Note 7. We use the unrestricted HRS sample, which, unlike the restricted sample, does not include pension plan descriptions provided by employers. As noted by Gustman, Steinmeier and Tabatabai (2010, Chapter 4), there are advantages and disadvantages to each dataset, and for a study like ours, it is not obvious whether one would be better than the other. For example, individuals' self-reports in the unrestricted data are subject to error, especially when it comes to identifying plan type. But in the restricted data, other pension attributes are erroneously reported by employers. Further, the proportion of HRS respondents for whom it is possible to obtain employee information is relatively low in the restricted sample. In the 2005 employer survey, for example, employer-provided plan descriptions were available for only 49 percent of the respondents who reported having a pension (p. 64).

Note 8 . In addition, public employees may leave public sector employment in their 50 s and then switch to private sector jobs. However, in our sample, we find little evidence for this phenomenon. Out of 392 government 
workers with non-zero sample weights whom we are able to track over time, only 6 individuals made such transitions between 2006 and 2008.

Note 9. Starting in 2006, the HRS clearly identifies government sector affiliation through questions KJ720 ("Are you employed by the government at the federal, state, or local level?") and KJ721 ("Would that be the federal, state, or local government?").

Note 10. We experimented with a lower cutoff, 1,250 hours per year, and found that our substantive results were not affected.

Note 11. Question KJ005 on the 2006 HRS questionnaire reads "Are you working now, temporarily laid off, unemployed and looking for work, disabled and unable to work, retired, a homemaker, or what?" Respondents are allowed to give multiple responses to this question. We excluded all workers who indicated "retired" as one of their responses. There were a total of 333 workers who did so (including part-time workers). Retired individuals were not asked their sector of employment during their working years.

Note 12. The proportion of workers who have more than one DB plan is relatively small: 2.2 percent in the private sector, 5.5 percent in the federal government, 3.0 percent in the state government, and 4.0 percent in the local government. Gustman, Steinmeier and Tabatabai (2010) do not include the present value of a worker's second DB plan in their calculations because there is a higher probability of confusion among workers with two DB plans who are asked to report plan details (p. 337).

Note 13. Some public employees are not covered by Social Security. They neither contribute to Social Security on their jobs nor collect Social Security benefits. Therefore, their wealth upon entering retirement is lower than their private sector counterparts, but so are the payroll tax contributions they made during their work lives. However, according to Gustman, Steinmeier and Tabatabai (2013, Table 7), the present values of Social Security benefits and taxes experienced by our HRS cohort are virtually identical, so there should be little to no effect on our findings.

Note 14. Further, they make a mortality adjustment to account for variability in the probability of receiving a benefit. However, there is no correction for the possibility of financial insolvency. Given that both public and private sector entities might renege on part or all of their obligations, it is not clear how this would bias estimates of public-private differentials.

Note 15. For some observations, Gustman, Steinmeier and Tabatabai (2010) impute values using mixed, hot-decking, and replacement methods. For more detail, see HRS (2006).

Note 16. All regressions use the HRS respondent sample weights. The HRS contains design-specific sampling error codes. Following the suggestion in the HRS documentation, we use the SVY command set in STATA to incorporate these sampling error codes into the calculation of the standard errors. For further details, see HRS (2008, pp. 5-6)

Note 17. A subset (2,174 workers) of our observations provided responses to the question, "How long have you been with your current employer?" Specifically, we can calculate it for 1,668 workers in the private sector, 92 federal workers, 192 state workers, and 222 local workers. If the 2006 response was not available, we added two years to the 2004 response provided that the worker was still on the same job in 2006 as in 2004 . The average tenure by sector is 12.6 in the private sector, 17.7 years in the federal government, 14.8 years in state government, and 17.4 years in local government. However, Altonji and Williams (2005) have argued persuasively that including tenure in an OLS model is inappropriate, because it is positively correlated with the error term in the likely event that individuals with low productivity have high quit and layoff propensities. Similarly, including tenure on the right-hand side in modeling the determinants of pension wealth could also lead to inconsistent estimates - where pensions are more generous, individuals are likely to stay on the job longer, ceteris paribus.

Note 18. In principle, one could take advantage of the panel nature of the data to estimate a fixed effects model. We do not take this tack for two reasons. First, we would lose 802 observations: only 1,694 workers in the 2006 basic sample were re-interviewed and had a positive hourly wage in 2008. Second, in a fixed effects model, the coefficients on the sectoral variables are identified off of worker transitions between employment sectors, of which there are very few between 2006 and 2008.

Note 19. We cannot control for union coverage because the HRS does not include this information in the 2006 wave. In any case, as Gittleman and Pierce (2012, p. 226) argue, controlling for unionization status does not seem appropriate, "because union wage premia probably do not reflect ability differences, and those in the public 
workforce would not likely take their public sector unionization rates with them if they were to move to the private sector."

Note 20. Recall from Table 1 that, on average, government workers at all levels of government are more likely to have DB plans and less likely to have DC plans than their private sector counterparts. These findings continue to hold in multivariate models that include the demographic variables in Table 3 (results are available upon request). The dramatic differences in the incidence of DB and DC pensions in the public and private sectors cannot be attributed to differences in worker characteristics.

Note 21. State and local government employees are significantly less likely to receive employer contributions (state workers are 17.4 percentage points and local workers are 19.4 percentage points less likely than private sector employees), but there is no statistically discernible difference between federal employees and their private sector counterparts along this dimension. In results not reported here, we show that apart from the case of federal workers, differences in the likelihood and amount of an employer contribution to a worker's DC plan(s) cannot be attributed to differences in demographic characteristics.

Note 22 . We also did the calculations assuming a lower interest rate, 3 percent, and the results were substantively very similar.

Note 23. As was mentioned in section 3, some respondents in our sample changed jobs between 2004 and 2006, which makes it impossible to determine whether their pension wealth in 2004 can be associated with a federal, state, local, or private sector job. For this reason, the sample for this analysis includes only those individuals who worked in the same job in 2004 and 2006.

Note 24. We add the annuitized pension wealth differentials to the differentials from the second rather than the fourth column of Table 3 because the latter embody employer DC contributions, which are already included in the pension wealth variable.

Note 25. U.S. Bureau of Labor Statistics (2006, p.8).

Note 26. U.S. Bureau of Labor Statistics (2008, p.8).

Note 27. U.S. Bureau of Labor Statistics (2008, p.7).

Note 28. See U.S. Office of Personnel Management. Employee contributions are mandatory.

Note 29. For purposes of this calculation, we use the method suggested by Blackburn (2008) to convert the coefficient on the Federal variable from Table 3 to a percentage change.

Note 30. See Congressional Budget Office $(2002,2012)$ and Blue Mass Group (2011) for discussions of this phenomenon at federal and sub-federal levels of government, respectively.

Note 31. An appendix table available upon request provides a list of the occupation categories that are available in the HRS, and the proportion of employees in each category.

Note 32. In the same way, the coefficients on the sectoral variables in our pension wealth equation (column (4) of Table 4) are not substantively changed when we augment it with the occupation variables.

\section{Copyrights}

Copyright for this article is retained by the author(s), with first publication rights granted to the journal.

This is an open-access article distributed under the terms and conditions of the Creative Commons Attribution license (http://creativecommons.org/licenses/by/3.0/). 